\title{
No Escape from Ethnicity? Confessions of an Accidental CNN Pundit
}

Jelena Subotic, Georgia State University

ABSTRACT As a political scientist with expertise in human rights and the Balkans, I was invited to provide critical commentary and analysis of Kosovo's declaration of independence in February 2008 for CNN International. I offered an analysis rooted in the understanding and interpretation of international law, foreign policy, and domestic politics of Serbia and Kosovo. While I was not surprised that my analysis was not popular in Serbiaafter all, I did argue that the independence of Kosovo was legitimate-I was surprised at the level of ethnic intensity and the broad-based hostile reaction to my CNN appearance in Serbia. This article first documents the harassment campaign I experienced. I then conduct textual analysis of the hate mail and online postings to offer insights about ethnicity's relation to identity, gender, and political analysis in the public sphere. I conclude by discussing how identities of researchers-as crafted by themselves and othershelp define analytical tools we use in scholarly inquiry.

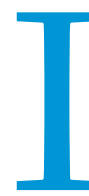
nternational relations scholars often despair at the gap between scholarly and policy work (Lepgold and Nincic 2001), and particularly the lack of comprehensive political analysis of foreign affairs in the media, especially television (Ignatieff 1999). In an attempt to contribute to a more analytical approach to international affairs in the mass media (and also because I thought it would be a fun thing to do!), I agreed to provide critical analysis of the events leading to and immediately following Kosovo's declaration of independence in February 2008 for CNN International. I sat in the CNN studio next to the anchor and provided on-and-off analysis and commentary of events as they were unfolding for about four and a half hours of airtime.

My appearance was received very well at CNN and I was consequently invited to do more interviews and analysis for CNN and other networks. The reaction in Serbia and from Serbian ex-pat communities, however, was hostile. I received more than 50 threatening e-mail messages and phone calls, including a call to my university's legal-services department. Many Serbian bloggers linked to the interview with extremely negative commentary. The video clip and my e-mail and Web site information also found its way onto a few Serbian online discussion forums, including a major international white supremacist Web site-Stormfront (Serbian chapter). Finally, the leading Serbian daily newspaper, Politika,

Jelena Subotic is assistant professor of political science at Georgia State University. She is the author of Hijacked Justice: Dealing with the Past in the Balkans (Cornell University Press, 2009). She received a Ph.D. in political science from the University of Wisconsin-Madison. Her research focuses on international relations theory, human rights, identity poltics, and the Balkans. She can be reached at jsubotic@gsu.edu. wrote a negative piece about me, flatteringly but inaccurately stating that I was "the centerpiece of CNN coverage of Kosovo's independence" and that I provided anti-Serbian commentary and analysis. The online version of the newspaper then opened this piece for readers' comments, and close to a 100 readers posted hostile messages about my performance, including threats to my family and myself.

So, what brought about this wrath? What did I say? Responding to a CNN anchor's question "what does this day [Kosovo declaration of independence] mean," I said:

This is an important day, this is an inevitable day, this day is long in the making, ever since the NATO war of 1999 that followed a campaign of ethnic cleansing by Serbs against ethnic Albanians. Kosovo has been in a state of limbo ever since 1999 and the situation was simply untenable domestically for Kosovo, for Serbia, and for the international community. So we are at a place now where we thought we would end in. What is important to emphasize is how interesting it is that [Kosovo] Prime Minister Thaci made it so clear that he wants Kosovo to be multiethnic; he made many references to this future European vision, protection of minorities, protection of the European spirit, which is really a very strong outreach both to the ethnic Serbs who remain in Kosovo but also to Serbia proper... There is a lot of domestic pressure in Serbia both on the prime minister and on the president not to give in. But they are in a bit of a bind here because if they continue with this hard-line stance of not recognizing Kosovo independence, of cooling off diplomatic relations with all the countries that recognize it, Serbia will again be isolated in the international community and its path toward European integration will be jeopardized. So both Prime Minister 
Kostunica and President Tadic need to be very careful here about not alienating European allies but also appeasing a very strong nationalist sentiment in Serbia. ${ }^{1}$

This interview segment was placed on the cnn.com Web site, and then copied onto aol.com and YouTube, where thousands more saw it. The reaction from Serbia was quick and violent. Within minutes of the segment airing, and then continuing on to the next two weeks or so, I began receiving hostile and threatening e-mail. The threats continued on Serbian blogs and online communities. Some of the messages and online postings were purely hateful and threatening in nature, a personally unpleasant experience shared and written about before by scholars (Valentine 1998; Dear 2001). Nevertheless, a few interesting substantive themes began to emerge that merit a deeper textual analysis of the correspondence I received.

\section{METHOD}

As an international relations scholar working in the constructivist tradition, I take language very seriously. I focus on discourse, on how meaning is mediated through language, speech acts, and text the data set to ascertain if there is a difference in the content of messages sent directly to me and the Web postings intended for other readers. To my surprise, I determined that the tone, character, and message consistency did not differ significantly in the two groups-what was said about me to third parties was also said to me directly. I concluded that the two data sources could be merged into one data set. I then began the qualitative textual analysis, which differs from its quantitative version in that it does not produce coding categories, but instead extracts critical cases and concepts for examination (Fursich and Lester 1996).

I began by first extracting the overarching "level one" concept of the text data set. I identified as the underlying theme of the text the relationship between the researcher's ethnicity and analysis (specifically, the relationship between my ethnic origin and the "ethnic inappropriateness" of my analysis). I named the level-one concept "ethnic identity." I then read the data set again, to extract "level two," or sub-concepts. Multiple readings of the same messages identified the following level-two concepts: ethnic membership, research motivation, ethnic responsibility, and gender/ sexuality. I then created themes that relate the level-one concept to the level-two concepts. Clustering the text in such a thematic

\section{The data I constructed from all the messages and postings show that my correspondents clearly internalized ethnicity in a primordial fashion. The overwhelming theme in all the comments I have received had to do with the issue of my ethnic identity, understood as organic "roots" and shared common ancestry. The main complaint is as follows: how could I, as a Serb, be critical of the Serbian position on Kosovo? As a Serb, I must understand the importance of Kosovo for "our nation," and should never support "the other side" on international television.}

(Checkel 2004). I believe in the social effects of texts, in their ability to bring changes to our knowledge and our actions (Fairclough 2003), in the intrinsic connection between textual and social processes (George 1994). To this end, I use textual analysis to empirically examine language practices to get at structures of meaning that order and systematize knowledge (Milliken 1999). Methodologically, textual analysis is particularly well suited for uncovering narrative themes and framing blocs. To get at a more robust discursive structure, textual analysis should be based on as many different texts by different authors who are presumed to be "authorized speakers of a dominant discourse" (Milliken 1999, 233).

The textual analysis that follows is the systematic examination of 56 e-mail messages and more than a hundred Web postings from 10 different blogs and online journals. Of the e-mail messages I received, 51 were explicitly negative in tone, while five were positive. Of the five positive messages, three were sent by self-identified Albanians, and two by self-identified Serbs, both of whom do not live in Serbia. Of the hundred or so Web postings, the overwhelming majority was negative; I have identified a total of three positive postings about my CNN appearance-all three from my personal acquaintances. Almost all e-mail messages (7 of 56 were in English) were written in Serbian, as well as virtually all of the Web postings.

I translated all messages and postings into English and read them for coherence, narrative consistency, and intent. I first read way allows us to uncover areas where shared understandings emerge. It is way for us to gather information about how people conceptualize ethnic identity and what it means to them, insights we can build on as we develop further theories about ethnicity and its political use.

\section{ETHNIC IDENTITY: IN AND OUT}

"You have the most beautiful Serbian name ... but unfortunately that is the only Serbian thing you have."

\section{-E-mail message from M.D. February 17, 2008}

Theories of ethnicidentity have traditionally fallen into three major camps-primordialist (Isaacs 1975; Shaw and Wong 1989), instrumentalist (Olzak and Nagel 1986; Haas 1993), and constructivist (Weber 1976; Anderson 1991). And while the literature has been steadily moving away from primordialist explanations of ethnicity towards understanding ethnic behavior as being rationally used for instrumental purposes (Kuran 1998), as an identity constructed on behalf of the state for reasons of power and control (Marx 1998), or used for nationalist political mobilization (Beissinger 2002), empirical researchers often face a paradox: since people we study view ethnicity in a primordial way, who are we as researches to superimpose constructivism onto our subjects (Gil-White 1999)?

The data I constructed from all the messages and postings show that my correspondents clearly internalized ethnicity in a 
primordial fashion. The overwhelming theme in all the comments I have received had to do with the issue of my ethnic identity, understood as organic "roots" and shared common ancestry. The main complaint is as follows: how could I, as a Serb, be critical of the Serbian position on Kosovo? As a Serb, I must understand the importance of Kosovo for "our nation," and should never support "the other side" on international television.

Furthermore, the language in which the messages were written matters. While my CNN interview was in English without subtitles, my correspondents wrote back in Serbian. This is significant in two ways: practically, my correspondents assumed I would read Serbian even though the only evidence of that would be my name, which they construed to be of Serbian descent and my accent, which indicated that I am not a native English speaker. More importantly, however, writing in Serbian indicates that my correspondents wanted to use a "private language," a language we could presumably share, but which no "outsider" speaks, to threaten and insult me, instead of the "public language" of English, in which my comments, my "ethnic betrayal" were initially made. The choice of language then further reinforces the construction of insider/outsider identities that my correspondents engaged in.

The fact that I provided political analysis that was incongruent with the Serbian position on Kosovo (keeping the province at all cost for reasons of territorial integrity, but also history, nation, and tradition) perplexed the viewers who wrote me. Many of them concluded that I, in fact, cannot be of Serbian origin:

\section{"Maybe she is Croatian?"}

"I sincerely hope that you are not of our ancestry but of Croatian or some other one, although your name does not indicate as much ..."

"I doubt she was born in Serbia."

"I am curious if she is a citizen of Serbia."

"Don't you find it a bit odd that nowhere in your biography you indicate your place of birth?"

"She is not a Serb, she is Croatian, a Catholic."

"I am not sure if she is ours or Croatian, but her $\mathrm{b}^{* * * * * *} \mathrm{t}$ deserves a medal."

"Look at this stupid whore. I heard she is Jewish from Serbia, no wonder she betrayed us. She would sell her mother for a handful of dollars. Damned whore."

However, what is even more interesting is that my correspondents were ready to revoke my ethnicity, even to deconstruct my identity because of my analysis of the Kosovo crisis:

"If I were you, I would be ashamed to ever again call myself a Serb."

"Aren't you ashamed to write against the interests of your (probably former) people?"

"[This is] from the city that was never yours."

"You have to thank them [Americans] for keeping you in their valuable country, by washing away your ancestry."

"If you no longer feel like a Serb, change your name, don't embarrass us any longer."

"Why isn't such a person forbidden from entering our country; her passport should be revoked. She should get Kosovo's passport if her country is not good enough for her."

"She got hold of America, and maybe forgot to speak Serbian."

"Does Serbia have smart and patriotic women? She should be urgently sent to Kosovo, and there she should decide which side is she on."
"If you can't stand beside and support what and who you are, you might as well shoot yourself."

"Do not bring shame on your name when you say ugly things about Serbia. Change it! Then it will be easier for us in Serbia to listen to a Jane or a Helen talk about Serbs and what they deserve."

In other words, my "approval" of Kosovo independence makes me no longer Serb. This move is interesting for a number of reasons. First, it indicates that, even for primordialists, ethnicity is more than thickness of blood. Ethnicity is determined not only by ancestry, but by a totalizing ideology. It is not enough for ethnic subjects to be of a shared group origin, but they need to share the ethnic group's political outlook as well to maintain their ethnic identity. Departure from an ethnic worldview can strip one of ethnicity as easily as if it were a club membership. Second, if ethnicity is something that can be revoked and deconstructed, then it was not that sticky to begin with. What this implies is that the primordial notion of ethnicity is much more elastic and all encompassing than our traditional understanding that revolves around beliefs in shared origin and common lineage. In fact, it might be more fruitful to conceive of a primordial view of ethnicity as much more political than purely cultural.

\section{ETHNIC IDENTITY AND RESEARCH MOTIVATION}

In line with this more politicized primordial view of ethnicity, my correspondents had a difficult time processing my apparent antiSerbian bias. So they offered some original ideas about why a Serbian-born researcher would not support the Serbian cause:

"If somebody had told me that a Serb (or maybe you are not Serb?) would say such horrible things on CNN only to advance your career at a third-rate American university, I would not have believed it. But I heard it myself, so I have to believe it."

"Is it the consequence of the poor education you received in the US, or your mixed marriage, or your work in quasi humanitarian organizations?"

"Because she is a Serb, her reasons are probably jealousy and personal revenge against a former boyfriend ... who left her for a more attractive Kosovo Serb. Maybe this is her five minutes and revenge that she long dreamed of, the culmination of her malice and damage that she can inflict on those who caused her pain."

"You twisted the facts precisely to please the US government so that they continue to lie to the American people."

"She represents CIA activities in Serbia."

"I know it is difficult to succeed as an immigrant, but one must retain some pride and dignity."

"You cannot be a professor at an American university if you advance Serbian interests."

Many writers assumed that I provided political analysis that was anti-Serbian in exchange for monetary benefits: ${ }^{2}$

"Congratulations, you have sold your soul to the devil. Truly curious, how you can sleep at night. You very well know that Kosovo is our sacred land and that it cost us many lives through the centuries. You feel that money is going to bring you happiness. It sure will temporarily. However, everyone gets what they deserve and you will as well."

"We hope that you charged heftily for your appearance."

"It is possible that the advantages of the American dream (house in the suburbs, SUV, benefits) somewhat compensate for your lack of conscience and morals." 
"Did they grease you well?"

"You sold yourself for a fistful of dollars."

"I would like to know what personal benefit you are reaping from this, other than noticing that you are constantly being called upon at CNN."

"You sold yourself cheaply."

"I guess you are proud for simply making a profit out of your Serbian origin and becoming a CNN star in the right time."

"Are you also paid by dirty money of Albanian mafia lobbyists?"

Some writers concluded that my analysis is the result of pathological ethnic self-hatred, a phenomenon written about in the context of Jewish dissent and Israeli politics (Finlay 2005):

"My first assumption was that this woman is an Albanian or maybe Croatian with Serbian sounding name ... It is more likely a Serbian-born person with shallow intellect and an inferiority complex called self-hatred, a well known psychologically induced intellectual abnormality."

"Why do you hate your people so much?"

"Why do you spew so much hatred against Serbs and Serbia?"

"Of all the people who are commenting on CNN about events in

Belgrade, do you have to be the most critical and most condemning?"

"Just another garbage who makes a career out of spitting at her own people."

"I really do not understand what is the reason for her bitterness against her own people."

These messages provide many interesting starting points for future research about ethnic identity. First, a primordial view of ethnicity sees ethnic subjects as fully controlled, guided, defined, and constrained by their ethnicity. There is no departure from ethnicity, no exit from its confines. Allegiance to the ethnic group is total, unquestionable, and complete. However, it is not just ethnic membership that is locked. Ethnicity is also political. Ethnic subjects are expected to support, even promote politicization of ethnicity, such as nationalist mobilization, entitlement, and ethnic "justice." This instrumentalization of ethnicity then becomes an intrinsic aspect of ethnic identity. If you are one of us, you better be on message. Claims against specific ethnic policies become inseparable from claims against the entire ethnic group (my criticism of Serbian Kosovo policy equals my hatred of Serbs). Because political claims are inalienable to ethnic identity, an ethnic subject's departure from ethnic politics creates cognitive dissonance; it seems impossible and nonsensical. This is why it is necessary to invoke ulterior motives to justify "exit from ethnicity," to make it legible, understandable, and meaningful.

\section{ETHNIC RESPONSIBILITY AND SHAME}

Many of the correspondents were upset that I made what they considered to be disparaging remarks against Serbia on foreign soil. It is not only the content of what I said, but where I said it that made it so unacceptable and offensive:

"Maybe we are a 'difficult' people, but the whole world does not need to know that. I fight with my children too, but God forbid somebody else says something bad about them."

"If you did not have the courage to say something more and deeper and analyze the situation more objectively, then you did not have to embarrass us on CNN."
"You must be aware that your statements further erode Serbia's reputation in the world. It is easier when a foreigner says something like this and not someone whose name indicates they are from this region."

"Shame on you to say such things about Serbs on foreign television."

"Anti-Serbian statements of this (Belgrade born) author ... are demonstrating hatred towards her own people in front of an audience of millions. After all, it is CNN."

"Even though I also disagreed on occasion with how Serbian government solved problems and conflict, I NEVER, NEVER spoke ill of the country I was born in, and I always defended it in front of others. That is called loyalty, patriotism and principle, or maybe you do not know the meaning of these words, you with your Ph.D.?"

"You should not have given such one-sided statements on CNN, considering your last name, which indicates you are of Serbian origin."

So, my correspondents argued that my criticisms of Serbian Kosovo policy contributed to Serbia's further embarrassment and decreasing international standing, that my statements amounted to a form of international shaming. However, the issue of shame was also directed at me, as the subject who should be ashamed of herself:

"Aren't you ashamed? Your poor child has a whore for a mother."

"Your children will be ashamed of you one day."

"Are you a Serb? Shame, shame."

"It is shameful to use other's misery to gain cheap points somewhere in the world."

"It is shameful that someone who is a professor of political science does not respect international law and is ready to violate it only in the case of Serbia."

"You bring shame on all of Serbia. But what goes around comes around. $\mathrm{B}^{* * * * ! "}$

"Shame on you! I will remember your name, and I am sure so will many others."

"I know how difficult it is here in America to be a Serb, but it would never cross my mind to say something like this. Shame, I am here ashamed for her."

"Who gives you the right to so absurdly insult the people you belong to, the people who have been fighting for centuries against many injustices, the people who are today in great despair? You should be ashamed!"

Shaming, however, is not enough. Some of my correspondents went a step further, charging that I, in fact, had committed treason by legitimating Kosovo's independence. The argument for this accusation is that, since independence of Kosovo is against Serbia's constitution (in preparation for the final showdown over the status of Kosovo, Serbia changed its constitution in November 2007 to claim Kosovo as an "inalienable part of Serbia"), proclaiming it legitimate is itself an unconstitutional act, equal to treason.

"I would like to inform you that after your appearance on CNN, the [Serbian] foreign ministry has opened criminal investigation against you because of your open and clear violation of the Constitutional Charter of the Republic of Serbia."

"Shame on you to speak against your people on CNN. Traitor!'

"I am not sure which part of former Yugoslavia you come from, but if you come from Serbia, you should know that you did some 
serious damage to your country. You are the worst kind of traitor I ever saw and heard, much worse than the local people you talk so badly about."

"You are garbage, rotten traitor."

"You are helping the hand that holds the knife aimed right at the heart of our people."

\section{ETHNICITY, GENDER AND VIOLENCE}

Some of the threatening e-mail was specifically sexual in nature, which introduces a new, gendered dimension to this correspondence:

"Obviously you have some serious problems. I guess because you are fat and ugly, so you left Serbia because you couldn't stand all those Belgrade's beautiful girls."

"You are so ugly. Aren't you ashamed of yourself, your child has a whore for a mother."

"Where are your roots from, you whore?"

"F*** your mother who raised you like that."

"A frog-like whore ... probably has not seen that thing in years

(maybe never) so is dealing with her issues in this way."

"You whore, do you think you are safe here in America? F*** everyone in your family."

"You are so ugly, you are so disgusting."

"Have all Albanians f*** you!"

"You abnormal whore!"

The gendered messages attempted to sexualize me and my political analysis. This serves two purposes: first, to dismiss me as a whore, a prostitute who has sold her opinion for material benefit and, second, to introduce a level of violence to the discourse. While it is clear that I did not receive hate mail because I was a woman, the nature of the comments was gendered and qualitatively different from correspondence male scholars received. For example, a textual analysis of hate mail Michael Dear (2001) received after the publication of his book identifies attacks on his competency, politics, and writing style (un-American trash, ecofreaky New Age naturalist, academic charlatanism, self-indulgent pompous pontification, evangelical zealot, postmodern dementia, quasi-colonial [ist]), but he is never called a whore or threatened with rape. A male colleague who has written op-ed pieces in a local newspaper about excesses of patriotism in the United States after September 11, 2001, received an avalanche of hate mail that questioned his competency, patriotism, morality, and national pride. The difference in content, however, does not mean that comments to men were not gendered; instead the construction of gender was different. Sunera Thobani analyzed the hate mail she had received after publicly arguing against the U.S. military intervention in Afghanistan and noted that her correspondents constructed her as an "angry lunatic woman of color," a "woman with a chip on her shoulder" (Thobani 2003). So, female researchers are assaulted on the basis of what "makes them women"-not competence or expertise-but gender, sexuality, appearance, and emotions (hate, anger, lunacy). Men, on the other hand, are attacked for what "makes them men"-competence, knowledge, and politics.

Much research has been done on the relationship between nationalism, masculinity, and violence (Yuval-Davis 1997), especially in the former Yugoslavia (Wilmer 2002). To the extent that my so-called anti-Serbian/pro-Kosovo analysis was perceived threatening to the Serbian national cause, the violence became transferred to the dimension of gender. For Serbian nationalists, it is offensive to hear commentary deemed unsupportive of Serbs and their cause. That the commentary comes from a woman is that much more upsetting and demeaning for nationalist masculinity. My identity as a (Serbian) mother and (Serbian) daughter is very important. ${ }^{3}$ In Serbian nationalist discourse, Serbian women have an obligation to create and nurture strong and "good" Serbs (Shiffman, Skrabalo, and Subotic 2002). When a woman becomes the source of national betrayal, it is not just one person betraying Serbia, but a whole lineage. My correspondents, then, become outraged that as a mother, a "bearer" of Serbian identity, I choose to offend or even disavow that identity. At the same time, they behave paternalistically, scolding me as a wayward daughter for having the audacity to disrespect the nation I belong to. ${ }^{4}$

Finally, I also received the straightforward threatening hate mail:

"Do you know that you invited the wrath of the Serbian people worldwide, that you will never be able to walk the streets without looking behind your shoulder? This is not a threat, I am just asking why did you need to spit on Serbs and Serbia like that?"

"Don't go out on the street."

"After such statements you should watch your head so that somebody doesn't kill you."

"If someone knows if her roots are in this region, let me know, I would love to cut the throats of all her close and distant relatives."

"Somebody says 'kill the sh**.' You deserve it."

"May you and your family slowly decompose from cancer."

"All criminals return, sooner or later, to the scene of the crime. And when she returns, she should be welcomed the way she deserves."

\section{CONCLUSION}

This experience has been instructive in many different ways.

Personally, my brief stint at $\mathrm{CNN}$ and its harassing aftermath taught me that for me at least, there may not be an escape hatch from ethnicity! Try as I might to de-ethnify myself, to cloak myself in the robes of an academic scholar, ethnicity comes back to define both me and my work. While I may assume that scholarship provides the neutrality, objectivity, and standing that would overcome ethnicity-it does not. Using your ethnicity as an analytical tool has its advantages, but it is also a powerful weapon that can be used against you.

However, I want to be careful not to essentialize about essentializing. I am obviously not making a generalizable claim about Serbian identity based on this experience. Since my data set is clearly not a random-sample design, the purpose of this article was not to draw sweeping conclusions about Serbian political culture. Having said that, this experience can open up new possibilities for research on ethnic identity and many aspects it encompasses-political, national, international, and even sexual. It also opened up space for inquiry into the relationship between ethnicity and political research. The many correspondents who attempted to revoke my ethnicity because of my ethnic "disloyalty" also attempted to exclude me from the discipline and practice of political science. For my correspondents, my ethnic identity should trump my research, analysis, and political opinion; it should invalidate my scholarly work, which should be judged primarily by my ethnicity. This attempt at exclusion is an interesting avenue for further research on the relationship between 
scholars and the subjects we study and the power relations that inevitably develop between them in the course of scholarly inquiry. If we understand identities as multiple, conflated, and constantly in the process of creation and recreation by ourselves and others (Kondo 1990), then we need to look more systematically at how researchers' identities-as perceived by their informants and their critics-define the analytical tools and barriers to research.

Finally, this episode has stressed both the perils and opportunities of presenting political research in the public sphere. While offering scholarly political analysis in the media and bridging the scholar/practitioner divide are all public goods, these moves come at some professional cost. The nature of mass media requires simplification, summation, and even de-contextualization. While my CNN analysis was, I hope, pithy and condensed, it is difficult to gauge its actual contribution to the production of knowledge. However, even with these personal and professional difficulties, I am convinced more than ever that as scholars, we have a responsibility and obligation to speak out on politically controversial issues and expand our analysis into the public arena. We should use these opportunities as teachable moments-both to present our work to the people who are affected by it, and to learn from people we study about what political facts mean to them and how they guide their actions.

\section{NOTES}

I would like to thank Duska Anastasijevic, Michael Barnett, Vojin Dimitrijevic, Mario Feit, Jeannie Grussendorf, Peter Lindsay, Irina Ljubic, Vladislav Mijic, Ana Miljanic, Dragana Nikolajevic, Gordan Paunovic, Leigh Payne, Doug Rose, Jason Sharman, Jovan Teokarevic, Ayse Zarakol, participants in the Georgia State University Political Science Faculty Colloquium, and two anonymous reviewers.

1. Kosovo was historically a province in Serbia. While granted significant autonomy during the communist era, under the rule of Serbian president Slobodan Milosevic, the majority Albanian population of Kosovo was systematically denied participation in civic and political life, and human rights abuses against the Albanian population were widespread. Responding to the increasingly harsh treatment by the Serbian government, Kosovo Albanians formed armed militias who entered into a protracted fight with the Serbian police in 1998 and 1999. In an attempt to rid Kosovo of insurgents, the Serbian police forces carried out a massive operation in 1999 where not only rebels but thousands of Albanian civilians were targeted for killing or deportation. This practice of "ethnic cleansing" has been documented by Human Rights Watch (2001). The charges of forced deportation were also included in the International Criminal Tribunal for the former Yugoslavia (ICTY) indictment against Slobodan Milosevic. See ICTY Prosecutor vs. Milosevic, Case No. IT-99-37-PT. In response to the increasing violence in Kosovo, NATO carried out an air campaign against Serbia in 1999. Serb troops withdrew from the province and Kosovo remained a United Nations protectorate until February 2008, when it unilaterally declared independence.

2. I have not been compensated for any of my media appearances.

3. Since many of my correspondents referred to "my child," I assume that they have concluded I am a mother from my personal Web site, which includes family pictures of my son.

4. I thank Leigh Payne, personal correspondence, for elaborating this point.

\section{REFERENCES}

Anderson, Benedict. 1991. Imagined Communities: Reflections on the Origin and Spread of Nationalism. London: Verso.

Beissinger, Mark R. 2002. Nationalist Mobilization and the Collapse of the Soviet State. New York: Cambridge University Press.

Checkel, Jeffrey. 2004. "Social Constructivisms in Global and European Politics: A Review Essay." Review of International Studies 30 (2): 229-44.

Dear, Michael. 2001. "The Politics of Geography: Hate Mail, Rabid Referees, and Culture Wars.” Political Geography 20 (1): 1-12.

Fairclough, Norman. 2003. Analysing Discourse: Textual Analysis for Social Research. New York: Routledge.

Finlay, W. M. L. 2005. "Pathologizing Dissent: Identity Politics, Zionism and the Self-Hating Jew.” British Journal of Social Psychology 44 (2): 201-22.

Fursich, Elfriede, and E. P. Lester. 1996. "Science Journalism under Scrutiny: A Textual Analysis of 'Science Times.'” Critical Studies in Mass Communication 13 (1): $24-43$.

George, Jim. 1994. Discourses of Global Politics: A Critical (Re)introduction to International Relations. Boulder: Lynne Reiner.

Gil-White, Francisco J. 1999. "How Thick Is Blood? The Plot Thickens .... If Ethnic Actors Are Primordialists, What Remains of the Circumstantialist/ Primordialist Controversy?” Ethnic and Racial Studies 22 (5): 789-820.

Haas, Ernst B. 1993. "Nationalism: An Instrumental Social Construction." Millennium 22 (3): 505-45.

Human Rights Watch. 2001. Under Orders: War Crimes in Kosovo. http://www. hrw.org/en/reports/2001/10/26/under-orders-war-crimes-kosovo.

Ignatieff, Michael. 1999. "The Stories We Tell: Television and Humanitarian Aid." Social Contract Journal 10 (1): 1-8.

Isaacs, Harold Robert. 1975. Idols of the Tribe: Group Identity and Political Change. New York: Harper \& Row.

Kondo, Dorinne K. 1990. Crafting Selves: Power, Gender, and Discourses of Identity in a Japanese Workplace. Chicago: University of Chicago Press.

Kuran, Timur. 1998. "Ethnic Norms and Their Transformation through Reputational Cascades." The Journal of Legal Studies 27 (2): 623-59.

Lepgold, Joseph, and Miroslav Nincic. 2001. Beyond the Ivory Tower: International Relations Theory and the Issue of Policy Relevance. New York: Columbia University Press.

Marx, Anthony W. 1998. Making Race and Nation: A Comparison of South Africa, the United States, and Brazil. Cambridge: Cambridge University Press.

Milliken, Jennifer. 1999. "The Study of Discourse in International Relations: A Critique of Research and Methods." European Journal of International Relations 5 (2): 225-54.

Olzak, Susan, and Joane Nagel. 1986. Competitive Ethnic Relations. Orlando: Academic Press.

Shaw, R. Paul, and Yuwa Wong. 1989. Genetic Seeds of Warfare: Evolution, Nationalism, and Patriotism. Boston: Unwin Hyman.

Shiffman, Jeremy, Marina Skrabalo, and Jelena Subotic. 2002. "Reproductive Rights and the State in Croatia and Serbia." Social Science and Medicine 54 (4): $625-42$.

Thobani, Sunera. 2003. "War and the Politics of Truth-Making in Canada." Qualitative Studies in Education 16 (3): 399-414.

Valentine, Gill. 1998. “"Sticks and Stones May Break My Bones”: A Personal Geography of Harassment." Antipode 30 (4): 305-32.

Weber, Eugen. 1976. Peasants into Frenchmen: The Modernization of Rural France, 1870-1914. Stanford: Stanford University Press.

Wilmer, Franke. 2002. The Social Construction of Man, the State, and War: Identity, Conflict, and Violence in Former Yugoslavia. New York: Routledge.

Yuval-Davis, Nira. 1997. Gender \& Nation. London: Sage. 